\title{
Immunohistochemical Localization of Intermediate Filament and S-100 Proteins in Several Non-endocrine Cells of the Human Pituitary Gland.
}

\author{
F. Marin, J. Boya, A. Lopez-Carbonell and A. Borregón \\ Department of Histology, Faculty of Medicine, University Complutense, Madrid, Spain
}

Received November 4, 1988

\begin{abstract}
Summary. The presence and distribution of glial fibrillary acidic protein, vimentin, neurofilament protein, cytokeratins No. 8 (52 Kd), No. 18 (45 Kd) and No. 19 (40 $\mathrm{Kd}$ ) and S-100 protein in pituicytes, folliculo-stellate cells, the epithelium of the Rathke's cysts and squamous cell nests of the pars tuberalis were investigated immunohistochemically by the peroxidase-antiperoxidase (PAP) method in eleven normal human pituitary glands. An identical immunostaining pattern was expressed by both folliculo-stellate cells and pituicytes. In both cell types the immunostaining for glial fibrillary acidic protein (GFAP), S-100 protein and vimentin was strongly positive. These results indicate the probable glial origin of the folliculo-stellate cell, and enlarge the group of glial cell types expressing vimentin. The coexpression of cytokeratins No. 8 and 19, both characteristic for simple epithelia, and S-100 protein was evident in the epithelial cells lining the Rathke's cysts and the squamous cell nests of the pars tuberalis. Furthermore, some epithelial cells of the Rathke's cysts co-expressed cytokeratins, S-100 protein and GFAP, a fact seldom reported and only in relation to rare neoplasms. The cytokeratin No. 18, characteristic for glandular epithelia, was not clearly demonstrated. Finally, the neurofilament protein was detected only in axons of the neurohypophysis; no immunopositive cells could be found throughout the adenohypophysis. Similarities in the antigenic patterns of these cell populations and the possible relation with their origin and nature are discussed.
\end{abstract}

The recent application of non-hormonal markers to the pituitary gland has allowed the immunocytochemical characterization of several cell types ultrastructurally well-known but whose origin, nature and function have not yet been established. Neurohypophyseal pituicytes and adenohypophyseal stellate (or folliculo-stellate) (FS) cells constitute this group of non-secretory cells (TAKEI et al., 1980;VILA-PORCILE and OLIVIER, 1984).

Several studies on the human pituitary gland have demonstrated that both cell types share two antigens classically considered glial cell markers: protein S-100, a cytoplasmic calcium-binding protein (LAURIOLA et al., 1984 ;GIROD et al., 1985; HAIMOTO et al., 1987; HÖFLER et al., 1984a; MORRIS and HITCHCOCK, 1985; IWAKI et al., 1986; VAN NASSAUW et al., 1987), and glial fibrillary acidic protein (GFAP) (HöFLER et al., 1984a; MORRIS and HITCHCOCK., 1985; IWAKI et al., 1986; VAN NASSAUW et al., 1987; VELASCO et al., 1982). These findings have supported the view that these cell types have a glial nature and probably a common neuroectodermal origin (MORRIS and HITCH COCK, 1985; VELASCO et al., 1982). This hypothesis is in agreement with the classical notion of the glial nature of pituicytes (TAKEI et al., 1980; REDECKER et al., 1987). However it introduces a new concept, namely, a portion of the adenohypophyseal cellular population must not derive from the ectodermal primitive stomodeum. This is contrary to the classical conception about the development of the anterior pituitary lobe.

On the other hand, it has been reported that the cells lining the Rathke's cysts of the pars intermedia of the human pituitary gland express a wide variety of antigenic markers including S-100 protein (HAIMOTO et al., 1987; MORRIS and HitchCOCK, 1985), GFAP (MORRIS and HITCHCOCK, 1985; VELASCO et al., 1982; TROJANOWSKI et al., 1984), keratin (ASA et al., 1981) and neuron-specific enolase (NSE) (MORRIS and Hiтchсоск, 1985; AsA et al., 1984). The demonstration that the majority of these cells also showed ACTH-immunoreactivity (ASA et al., 1984) and other 
adenohypophyseal hormones (CIOCCA et al., 1984), enlarged the pool of antigens expressed by these cells. Therefore the outstanding antigenic heterogeneity of these cystic structures deserves mention.

Except for GFAP, there is a dearth of knowledge concerning the content of other intermediate filaments (IFs) in the human pituitary gland; even contradictory results have been reported. AsA et al. (1981) indicated that only cells lining the Rathke's cysts and the squamous cell nests of the pars tuberalis express cytokeratin. On the contrary, HöFLER et al. (1984b) described the presence of cytokeratin in all the adenohypophyseal secretory cells. To our knowledge there is only one reference concerning the expression of vimentin in the human pituitary gland (HöFLER et al., 1984a), these authors pointing out that nearly $10 \%$ of S-100-positive FS cells contain vimentin.

In previous works we have demonstrated the presence of vimentin in the FS cells, marginal cells of the pituitary cleft, glial cells of the pars intermedia and pituicytes in three mammalian species (MARín et al., $1989 \mathrm{a}, \mathrm{b})$. The aim of the present immunocytochemical study is to determine the presence and distribution of S-100 protein and the IFs cytokeratin, GFAP, vimentin and neurofilament protein on these same cells in the human pituitary gland.

\section{MATERIAL AND METHODS}

Eleven normal adult pituitary glands obtained during autopsy were used in this study. Five were fixed in Bouin-solution and six in methacarn $(60 \%$ methanol, $30 \%$ chloroform, $10 \%$ glacial acetic acid) for 12-16 h at $4^{\circ} \mathrm{C}$ and embedded in paraffin. Serial sections were cut at $5 \mu \mathrm{m}$ and mounted on glass slides for immunolabelling. After dewaxing in xylene, the sections were washed in phosphate-buffered saline (PBS) (pH 7.4, 0. $01 \mathrm{M})$. Endogenous peroxidase activity was inhibited with a bath of $3 \% \mathrm{H}_{2} \mathrm{O}_{2}$ in methanol.

A three-step immunoperoxidase procedure for the assessment of polyclonal antibodies was carried out (STERNBERGER et al., 1970). Slides were incubated at room temperature in normal swine serum diluted 1 : 30 in PBS to avoid background staining. Afterwards sections were incubated overnight at $4^{\circ} \mathrm{C}$ with polyclonal rabbit immunoglobulins to bovine S-100 protein (Dakopatts, Denmark) diluted 1:320 and with polyclonal rabbit immunoglobulins to bovine GFAP (Dakopatts, Denmark) diluted 1:300. Sections were washed with PBS and then sequentially incubated (30 min incubation at room temperature) with swine antirabbit immunoglobulins antiserum at a dilution of 1 : 45 and horseradish peroxidase-rabbit antihorseradish peroxidase immune complexes (PAP) (Dakopatts, Denmark) diluted 1:100. Antibody localization was effected by a peroxidase reaction using 3-3'-diaminobenzidine tetrahydrochloride (Sigma, St. Louis, MO) as chromogen. Sections were counterstained with haematoxylin, dehydrated and mounted with Eukitt (Kindler, Freiburg).

For monoclonal antibody studies, we applied the indirect method of the immunoperoxidase technique according to TAYLOR (1986). After incubation with normal swine serum, slides were incubated at room temperature for $30-40 \mathrm{~min}$ in the following antibodies: monoclonal mouse antibody to human vimentin (Dakopatts, Denmark) diluted 1:4 ; monoclonal mouse antibody to human neurofilament (Dakopatts, Denmark) diluted 1:100; monoclonal PKK-1 antibody (Labsystems Inc., Finland) diluted $1: 100$. This antibody reacts with cytokeratins No. $8(52 \mathrm{Kd})$, No. 18 (45 Kd) and No. 19 (40 Kd) (HolThÖFER et al., 1983); and monoclonal PKK- 3 antibody (Labsystems Inc., Finland) diluted $1: 40$, which reacts with cytokeratin No. 18 (45 Kd) (VIRTANEN et al., 1985). These were then incubated for 30 minutes with peroxidaseconjugated rabbit anti-mouse immunoglobulin anti-

Table 1. Immunoreactivities of different cell types for intermediate filaments and S-100 protein.

\begin{tabular}{lcccccc}
\hline Cellular type & GFAP & VIM & PKK-1 & PKK-3 & NF & S-100 \\
\hline Folliculo-stellate cells & +++ & +++ & - & - & - & ++ \\
Rathke's cysts epithelium & +++ & + & +++ & + & - & +++ \\
Pars tuberalis & + & + & +++ & + & - & ++ \\
squamous cell nests & +++ & +++ & - & - & - & ++ \\
Pituicytes & - & - & - & - & +++ & - \\
Nerve fibers & & - &
\end{tabular}

- : No staining, + : weak, ++ : moderate, +++ : strong staining.

VIM : vimentin, PKK-1 : cytokeratins No. 8, 18 and 19, PKK-3 : cytokeratin No. 18, NF : neurofilament. 

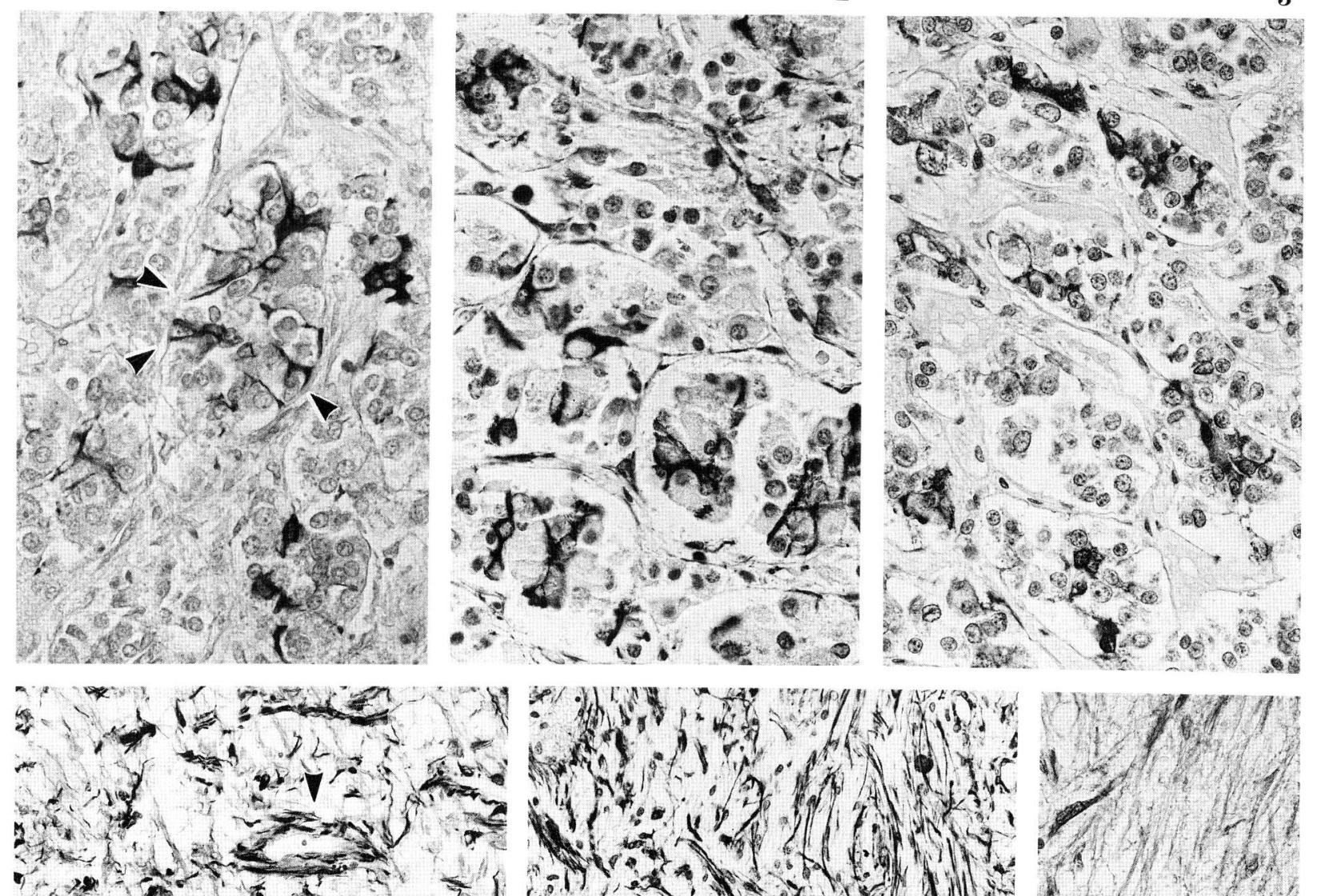

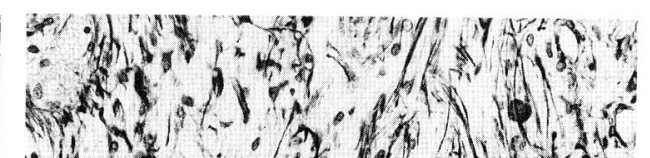

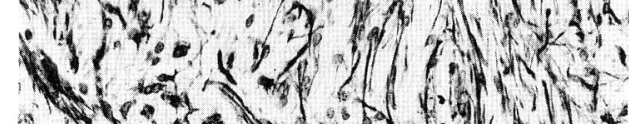

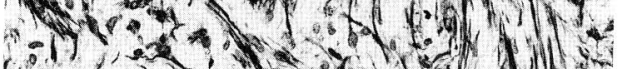

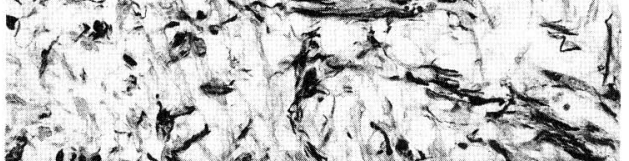

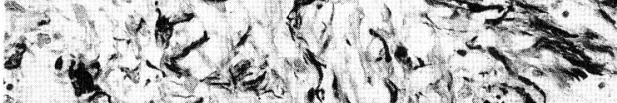

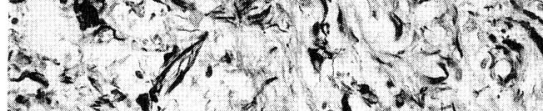

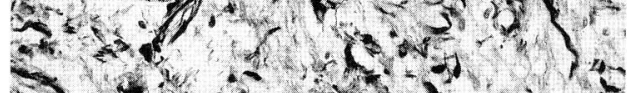
$32+1+2 x^{2}$

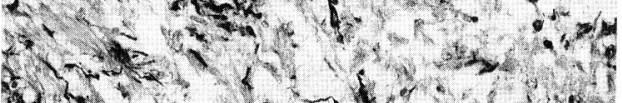

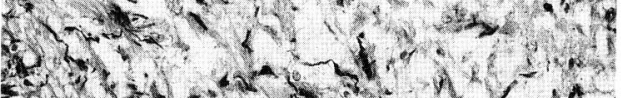

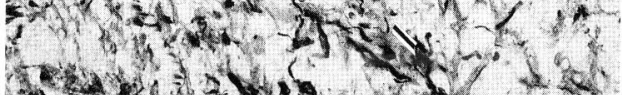
cot $12 x+2$
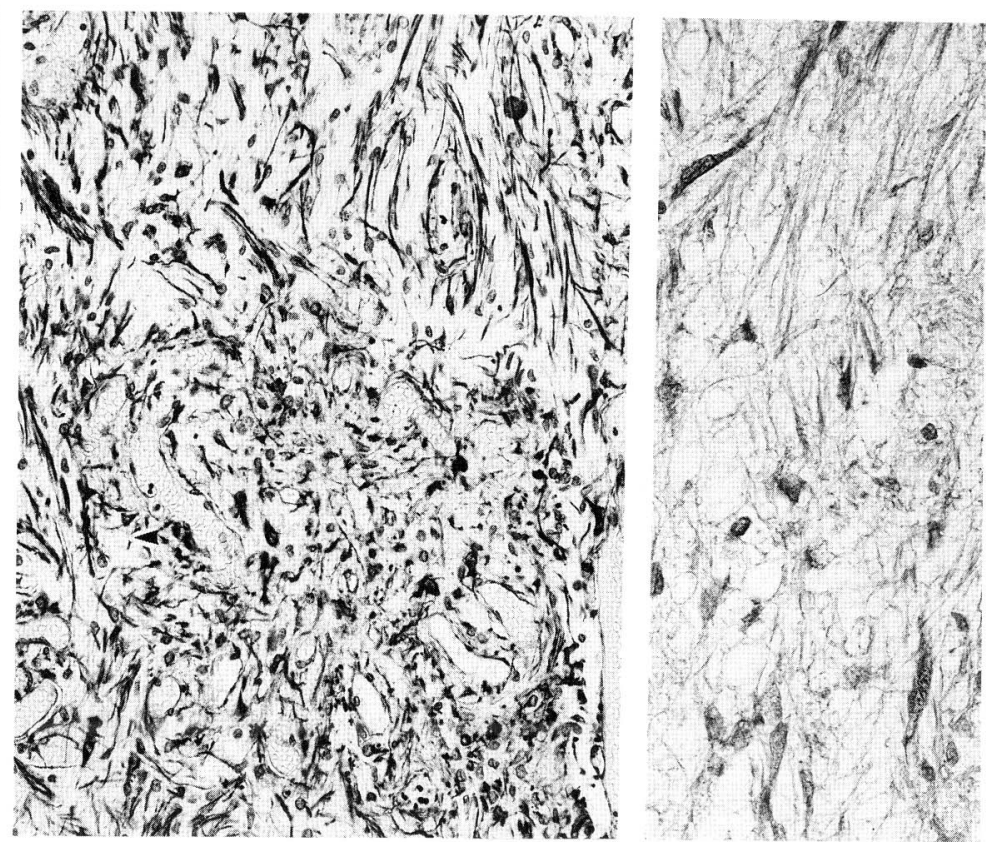

4

Fig. 1. Pars distalis. GFAP-immunostained stellate cells with slender cytoplasmic processes that occasionally reach the vasculoconnective septa (arrowheads). $\times 340$.

Fig. 2. Pars distalis. Vimentin-immunostained stellate cells with cytoplasmic processes between immunonegative glandular secretory cells. $\times 350$.

Fig. 3. Pars distalis. S-100-immunostained stellate cells showing a similar disposition to those of Figures 1 and 2. $\times 350$.

Fig. 4. Neurohypophysis. GFAP- immunostained pituicytes. Abundant immunostained processes surrounding a blood vessel (arrowheads). $\times 175$.

Fig. 5. Neurohypophysis. Numerous vimentin-immunostained pituicytes located throughout the neural lobe. $\times 175$.

Fig. 6. Neurohypophysis. S-100-immunostained pituicytes. Note the immunopositivity of the cell nuclei. $\times 340$. 

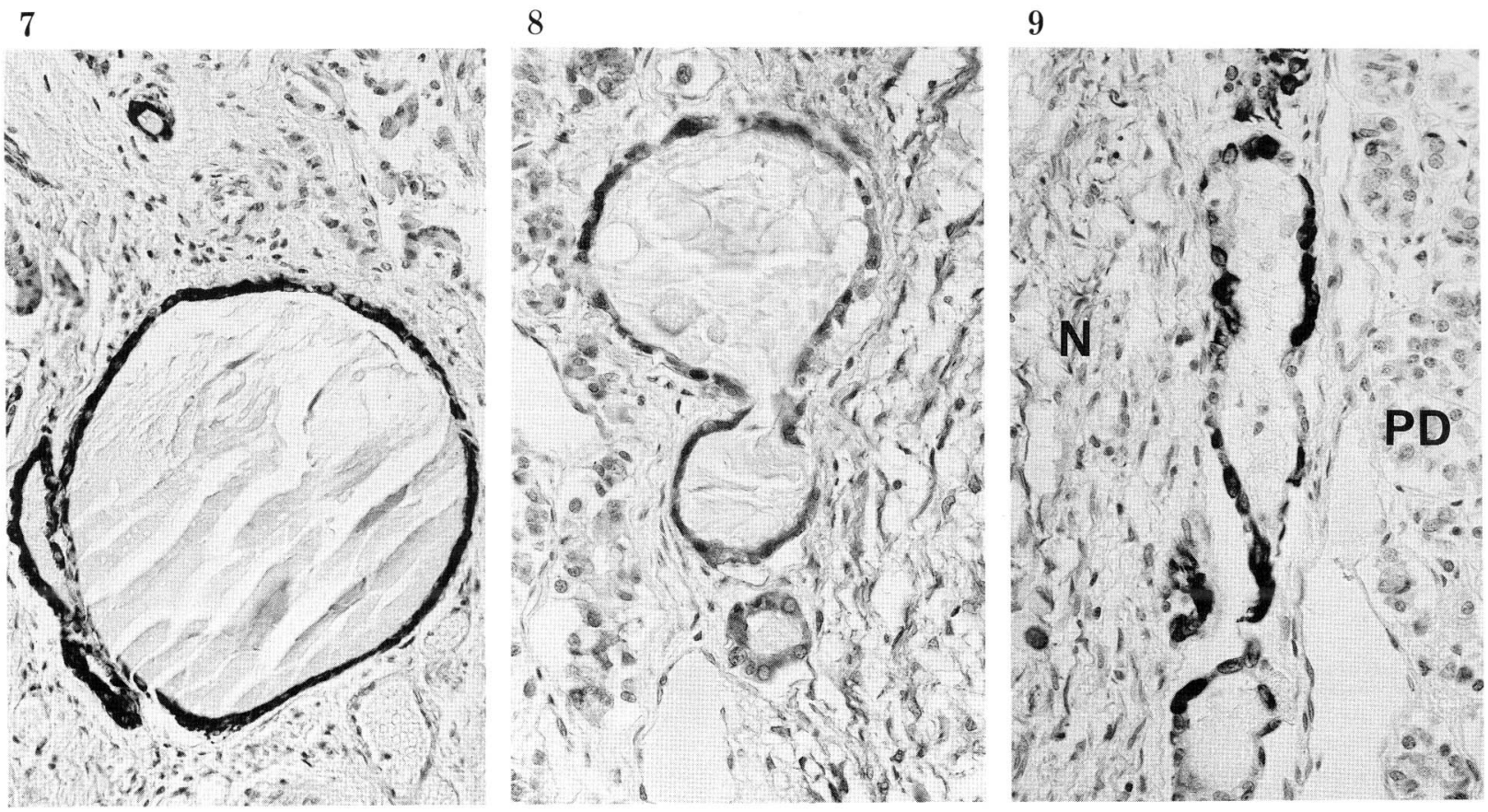

Fig. 7. Pars intermedia. PKK-1-immunopositive epithelial cells lining the Rathke's cysts. $\times 220$.

Fig. 8. Pars intermedia. S-100 immunoreactivity is expressed by the majority of the cells lining the Rathke's cysts. $\times 290$.

Fig. 9. Pars intermedia. Note the coexistence of GFAP-immunopositive and GFAP-immunonegative epithelial cells lining the Rathke's cysts. $N$ neurohypophysis, $P D$ pars distalis. $\times 290$.

bodies (Dakopatts, Denmark) diluted $1: 30$. Antibody localization was determined with a peroxidase procedure as described above for the polyclonal antibody technique.

The specificity of the immunocytochemical reaction was tested by substitution of the primary antibodies for non-immune swine serum and by the omission of the PAP-complex or the peroxidaseconjugated rabbit anti-mouse IgG. All negative controls failed to show any immunoreactivity. Positive controls of several normal tissues were included for each antibody.

Methacarn-fixed material demonstrated a superior preservation of the intermediate filaments. However, Bouin-fixed material was necessary for a good preservation of S-100 protein. The digestion of the sections with pepsin (Sigma, St. Louis, MO) $0.4 \%$ in $\mathrm{HCl}$ $0.01 \mathrm{~N}$ for $15 \mathrm{~min}$, did not enhance the immunoreactivity.

\section{RESULTS}

The immunoreactivity patterns are summarized in Table 1. The population of adenohypophyseal stellate cells showed an intense immunoreactivity for proteins GFAP, vimentin and S-100 (Figs. 1-3). These cells were interspersed between immunonegative glandular secretory cells. Their slender cytoplasmic processes were seen reaching the connective septa and the blood vessel walls, encircling isolated secretory cells or lining colloid-filled follicle cavities in the pars distalis. On serial-cut sections, most GFAPpositive cells were also stained for proteins S-100 and vimentin. On the other hand, many S-100 and vimentin-positive cells did not show any reaction with anti-GFAP polyclonal antibodies.

The neurohypophyseal pituicytes presented an immunostaining pattern analogous to stellate cells (Figs. 4-6). GFAP-positive pituicytes showed a tendency to be located in the pituitary stalk and in the adjacent region of the neural lobe, while vimentin and S-100 immunoreactive pituicytes could be seen more 

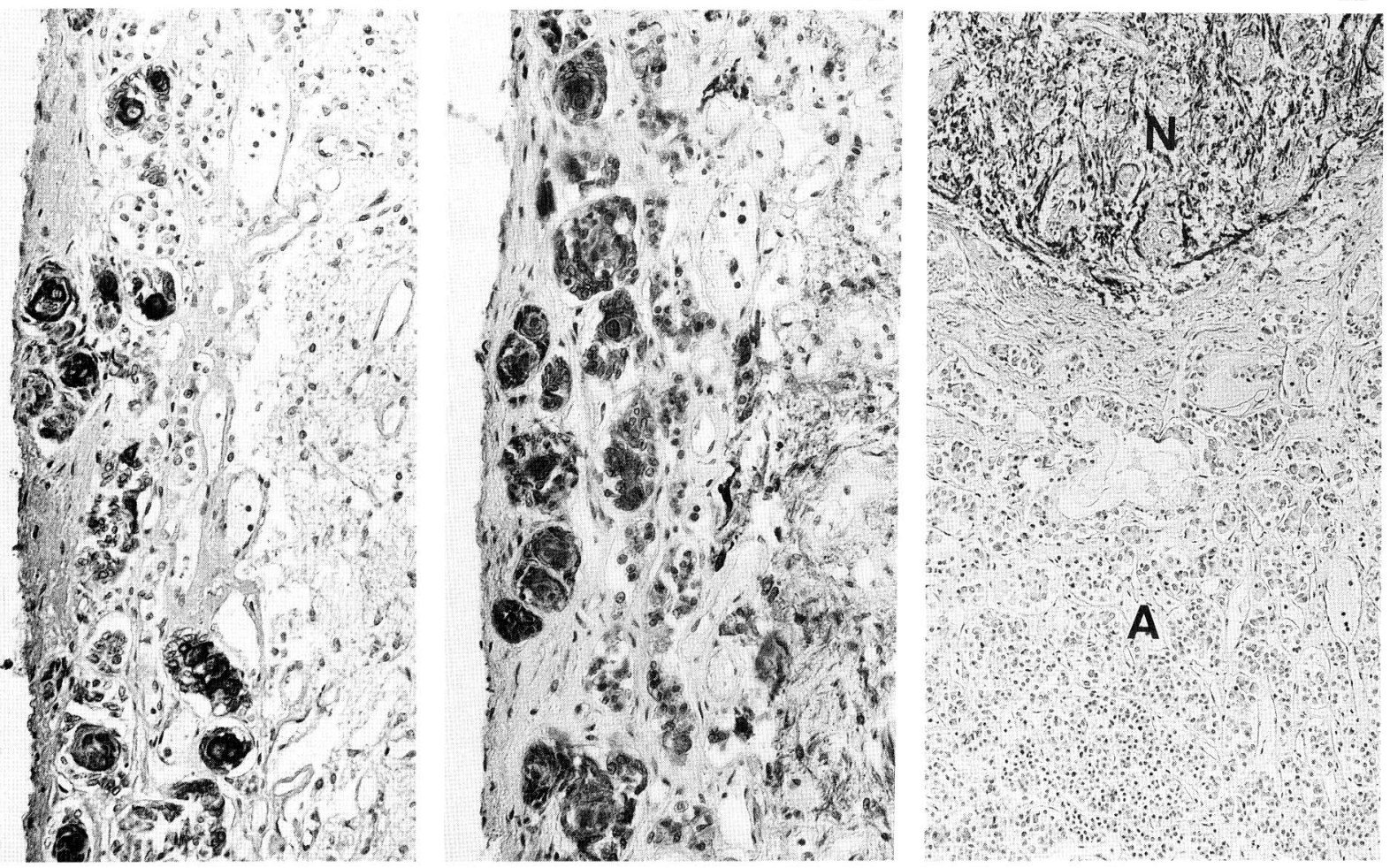

Fig. 10. Par tuberalis. Squamous cell nests expressing PKK-1 immunoreactivity. $\times 175$.

Fig. 11. Pars tuberalis. S-100 immunoreactivity in the squamous cell nests. $\times 175$.

Fig. 12. Immunopositive nerve fibers for neurofilament protein in the neurohypophysis $(N)$. Note the absence of immunoreactivity in the adenohypophysis $(A) . \times 95$.

widely dispersed throughout the whole neurohypophysis.

The epithelium lining the Rathke's cysts of the pars intermedia showed a heterogeneous antigenic endowment. The majority of these cells were strongly positive for proteins PKK-1 and S-100 (Figs. 7, 8). On serial-cut sections we found that some of these cells also showed a strong GFAP-immunoreactivity. GFAP-positive cells, though in lesser numbers, appeared in nearly all cysts of the pars intermedia (Fig. 9). A few cells immunoreactive for PKK-3 and vimentin, usually weakly stained, could only occasionally be seen lining these cysts.

The squamous cell nests of the pars tuberalis expressed an immunostaining pattern similar to the epithelium of the Rathke's cysts, strongly immunostained for PKK-1 (Fig. 10) and weaker for proteins S-100 (Fig. 11) and GFAP. The immunoreaction for vimentin and PKK-3 in the squamous cell nests was inconsistent and of weak intensity.

A wide network of immunostained nervous fibers was demonstrated in the neurohypophysis using the anti-neurofilament monoclonal antibody. Occasionally bundles of immunoreactive fibers were seen penetrating into the pars intermedia and even within the pars distalis. We were never able, however, to observe any neurofilament-positive cell body in the pituitary gland (Fig. 12).

\section{DISCUSSION}

In the present study we have demonstrated the distribution of several IF proteins and S-100 protein in the normal adult human pituitary gland.

The large number of vimentin-positive FS cells in the pars distalis and tuberalis was striking. HöFLER et al. (1984a) pointed out that nearly $10 \%$ of the human adenohypophyseal S-100-positive FS cells were immunolabelled with anti-vimentin antibodies. Our discovery of a larger proportion of vimentin-positive FS cells may be related to a better preservation of 
this IF protein in the methacarn-fixed tissue, although individual variations cannot be excluded.

In agreement with other authors (HöFLER et al., 1984a; MORRIS and HITCHCOCK, 1985), we suggest the existence of different types of FS cells: a) cells with S-100, vimentin and GFAP immunoreactivity, located mainly at the periphery of the pars distalis and b) cells with S-100 and vimentin immunoreactivity but GFAP-negative with a clear tendency to be placed in the central region of the pars distalis. This immunocytochemical variability probably reflects different functional states within the same cell population. In fact, it has been demonstrated that reactive astrocytes and pituicytes show an enhanced synthesis and accumulation of GFAP (VELASCO et al., 1982; LUDWIN, 1985).

The coexpression of GFAP and vimentin has been largely demonstrated in embryonic, adult, reactive and neoplastic astrocytes (TAKAMIYA et al., 1988). The coexistence of both antigens in the FS cells may point toward the possible glial nature of this cell type. This hypothesis has been previously suggested by ultrastructural and immunocytochemical findings (CoCChIA and MiAni, 1980; NAKAJIMA et al., 1980; VELASCO et al., 1982; MORRIS and HiTCHCOCK, 1985). Furthermore, the identical spectrum of antigenic markers that we have found in pituicytes and FS cells could suggest a close relationship between both cell types. The presence of vimentin has been recently described in pituicytes of several vertebrates (MARÍN et al., $1989 \mathrm{a}, \mathrm{b})$ though not yet in humans. Our findings therefore increase the group of glial cell types expressing vimentin.

Occasionally we observed cells immunopositive for S-100, vimentin and GFAP lining completely or partially small follicular cavities in the pars distalis and tuberalis. Sometimes, only slender immunoreactive cytoplasmic processes could be seen between two adjacent immunonegative cells reaching the follicular lumen. These findings complement previous data reporting that several types of glandular secretory cells line these follicular cavities (CIOCCA et al., 1984). According to our results this lining is rather mixed. The absence of cytokeratin expression in these cells suggests that these structures are not remnants of the Rathke's pouch, as previously stated by others (HoR VATH et al., 1974; CIOCCA et al., 1984; Gon, 1987).

The great complexity of the immunocytochemical pattern showed by the epithelial cell lining the Rathke's cysts of the pars intermedia is striking. These structures have been classically considered as remnants of the Rathke's pouch (SHANKLIN, 1951). They show a variable cell population immunoreactive for
S-100 (MORRIS and HiTCHCOCK, 1985; HAIMOTO et al., 1987), GFAP (VELASCO et al., 1982; TROJANOWSKI et al., 1984; MORRIS and HiTCHCOCK, 1985), keratin (ASA et al., 1981), neuron-specific enolase (AsA et al., 1984; MORRIS and HITCHCOCK, 1985) and several adenohypophyseal hormone secreting glandular cells (ASA et al., 1984; CiocCA et al., 1984). Our findings using PKK-1 and PKK-3 monoclonal antibodies show that the most cells lining the Rathke's cysts contain cytokeratins No. 8 (52 Kd) and/or No. $19(40 \mathrm{Kd})$, both characteristic for simple epithelia (COOPER et al., 1985), whereas cytokeratin No. 18 (45 Kd), characteristic for glandular epithelia (RAMAEKERS et al., 1983) could not be clearly demonstrated.

However, the most unexpected finding was the coexpression of GFAP and cytokeratins in a part of the cell population lining the Rathke's cysts. This feature has been seldom described, and then only in relation to uncommon neoplasms such as choroid plexus tumors (Doglioni et al., 1987), mixed tumors of the salivary glands(ACHTSÄTTER et al., 1986) and some myoepithelial cells of normal salivary glands (STEAD et al., 1988). Although cross-reactivity cannot be completely excluded, the great antigenic heterogeneity of these cells suggests a great pluripotentiality and a capability of cosynthetizing distinct IF proteins in a way similar to neoplastic cells.

The similar immunostaining pattern for IFs and S-100 protein observed in the squamous cell nests of the pars tuberalis and in the cells lining the Rathke' $s$ cysts could suggests a relationship between them. This would be in agreement with the view of the squamous cell nests as remnants of the Rathke's pouch (CARMICHEL, 1931) rather than being derived from the metaplastic transformation of some glandular secretory cells of the pars tuberalis as suggested by ASA et al. (1983).

In spite of the presence of neuron-specific enolase reported in pituitary glandular secretory cells (ASA et al., 1984 ;HÖFLER et al., 1984a; MORRIS and HITCH. COCK, 1985; VAN NASSAUW et al., 1987), the immunolocalization of neurofilament proteins in our material was only detected in the nerve fibers. However, no immunoreactive cell bodies were observed anywhere in the pituitary gland. 


\section{REFERENCES}

Achtstätter, T., R. Moll, A. Anderson, C. Kuchn, S. Pitz, K. Schwechheimer and W. W. Franke: Expression of glial filament protein (GFP), in nerve sheaths and non-neuronal cells reexamined using monoclonal antibodies, with special emphasis on the co-expression of GFAP and cytokeratins in epithelial cells of human salivary glands and pleomorphic adenomas. Differentiation 31:206-227 (1986).

Asa, S. L., K. Kovacs, J. M. Bilbao and G. Penz: Immunohistochemical localization of keratin in craniopharyngiomas and squamous cell nests of the human pituitary. Acta Neuropathol. (Berl.) 54: 257-260 (1981).

: The pars tuberalis of the

human pituitary. A histologic, immunohistochemical, ultrastructural and immunoelectron microscopic analysis. Virchows Arch. (Pathol. Anat.) 399: 49-59 (1983).

Asa, S. L., N. Ryan, K. Kovacs, W. Singer and P. J. MARANGOS: Immunohistochemical localization of neuron-specific enolase in the human hypophysis and pituitary adenomas. Arch. Pathol. Lab. Med. 108: 40-43 (1984).

Carmichel, H. T.: Squamous epithelial nests in the hypophysis cerebri. Arch. Neurol. Psychiat. 26: 966-975 (1931).

Ciocca, D. R., L. A. Puy and A. O. Stati: Constitution and behavior of follicular structures in the human anterior pituitary gland. Amer. J. Pathol. 115: 165-174 (1984).

Cocchia, D. and N. Miani: Immunocytochemical localization of the brain-specific S-100 protein in the pituitary gland of adult rat. J. Neurocytol. 9: 771-782 (1980).

Cooper, D., A. Schermer and T. Sun: Classification of human epithelia and their neoplasm using monoclonal antibodies to keratins: strategies, applications, and limitations. Lab. Invest. 52: 243-256 (1985).

Doglioni, C., P. Dell' Orto, G. Coggi, P. Iuzzolino, L. Bontempini and G. Viale: Choroid plexus tumors. An immunocytochemical study with particular reference to the coexpression of intermediate filament proteins. Amer. J. Pathol. 127: 519-529 (1987).

Girod, C., J. Trouillas and M. P. Dubois: Immunocytochemical localization of S-100 protein in stellate cells (folliculo-stellate cells) of the anterior lobe of the normal pituitary. Cell Tiss. Res. 241: 505-511 (1985).

GoN, G.: The origin of ciliated cell cysts of the anterior pituitary. An experimental study in the rat. Virchows Arch. A 412: 1-9 (1987).

Haimoto, H., S. Hosoda and K. Kato: Differential distribution of immunoreactive S-100- $\alpha$ and S-100- $\beta$ proteins in normal nonnervous human tissues. Lab. Invest. 57 : 489-498 (1987).

Höfler, H., G. F. W Alter and H. DenK: Immunohistochemistry of folliculo-stellate cells in normal human adenohypophyses and in pituitary adenomas. Acta Neuropathol. (Berl.). 65: 35-40 (1984a).
Höfler, H., H. DENK and G. F. W ALTER: Immunohistochemical demonstration of cytokeratins in endocrine cells of the human pituitary gland and pituitary adenomas. Virchows Arch. (Pathol. Anat.) 404: 359-368 (1984b).

Holthöfer, H., A. Miettinen, R. Paasivuo, V.-P. Lehto, E. Linder, O. Alfthan and I. Virtanen: Cellular origin and differentiation of renal carcinomas. A fluorescence microscopic study with kidney-specific antibodies, antiintermediate filament antibodies, and lectins. Lab. Invest. 49: 317-326 (1983).

Horvath, E., K. Kovacs, G. Penz and G. Ezrin: Origin, possible function and fate of "follicular cells" in the anterior lobe of the human pituitary. An electron microscopic study. Amer. J. Pathol. 77: 199-212 (1974).

Iwaki, T., A. Kondo, I. Takeshita, H. Nakagaki, K. Kitamura and J. TAKeishi: Proliferating potential of folliculo-stellate cells in human pituitary adenomas. Immunohistochemical and electron microscopic analysis. Acta Neuropathol. (Berl.) 71: 233-242 (1986).

Lauriola, L., D. Cocchia, S. Sentinelli, N. Maggiano, G. MAIRA, and F. MichetTi: Immunohistochemical detection of folliculo-stellate cells in human pituitary adenomas. Virchows Arch. (Cell Pathol.) 47: 189-197 (1984).

Ludwin, S. K: Reaction of oligodendrocytes and astrocytes to trauma and implantation. A combined autoradiographic and immunohistochemical study. Lab. Invest. 52: 20-30 (1985).

Marin, F., J. Boya and A. Lopez-Carbonell: Immunocytochemical localization of vimentin in the posterior lobe of the cat, rabbit and rat pituitary gland. Acta Anat. (Basel) 134: 184-190 (1989a)

- : Immunocytochemical localization of vimentin in stellate cells (folliculo-stellate cells) of the rat, cat and rabbit pituitary pars distalis. Anat. Embryol. 179: 491-495 (1989b).

Morris, C. S. and E. Hiтchсоск: Immunocytochemistry of folliculo-stellate cells of normal and neoplastic human pituitary gland. J. Clin. Pathol. 38: 481-488 (1985).

Nakajima, T., H. Yamaguchi and K. Takahashi: S-100 protein in folliculo-stellate cells of the rat pituitary anterior lobe. Brain Res. 191: 523-531 (1980).

Ramaekers, F., A. Huysmans, O. Moesker, A. Kant, P. JAP, C. Herman and P. VooIJs: Monoclonal antibody to keratin filaments, specific for glandular epithelia and their tumors. Use in surgical pathology. Lab. Invest. 49: 353-361 (1983).

Redecker, P., W. Wittkowski and K. Hoffmann: Glial cells positive for glial fibrillary acidic protein in the neurohypophysis of the Djungarian hamster (Phodopus sungorus). An immunohistochemical and ultrastructural study. Cell Tiss. Res. 249: 465-471 (1987).

Shanklin, W. M.: The incidence and distribution of cilia in the human pituitary with a description of microfolicular cysts derived from Rathke's cleft. Acta Anat. (Basel) 11: 361-382 (1951). 
Stead, R. H., A. H. Oizilbash, T. O. Kontozoglou, A. DeAN DAYA and R. H. Riddell: An immunohistochemical study of pleomorphic adenomas of the salivary gland: glial fibrillary acidic protein-like immunoreactivity identifies a major myoepithelial component. Human Pathol. 19: 32-40 (1988).

Sternberger, L. A., P. H. Hardy, Jr. J. J. Cuculis and H. G. Meyer: The unlabeled antibody enzyme method of immunohistochemistry. Preparation and properties of soluble antigen-antibody complex (horseradish PAP) and its use in identification of Spirochetes. J. Histochem. Cytochem. 18: 315-333 (1970).

Takamiya, Y., S. Kohsaka, S. Toya, M. Otani and Y. TsuKADA: Immunohistochemical studies on the proliferation of reactive astrocytes and the expression of cytoskeletal proteins following brain injury in rats. Devel. Brain Res. 38: 201-210 (1988).

Takei, Y., S. Seyama, G. S. Pearl and G. T. Tindall: Ultrastructural study of the human neurohypophysis. II. Cellular elements of neural parenchyma, the pituicytes. Cell Tiss. Res. 205: 273-287 (1980).

TAYloR, C. R.: Immunomicroscopy: a diagnostic tool for the surgical pathologist. In: (ed. by) J. L. BENNINGTON: Major problems in pathology, Vol. 19. Saunders Co., Philadelphia, 1986 (p. 23-42).

Trojanowski, J. Q., D. Gordon, M. Obrocka, and V. M-Y. LEE: The developmental expression of neurofilament and glial filament protein in the human pituitary gland: An immunohistochemical study with monoclonal antibodies. Devel. Brain Res. 13: 229-239 (1984).
Van Nassauw, L., F. Harrison, P. Cras and M. CalLEBAUT: Immunohistochemical localization of S-100 protein, glial fibrillary acidic protein, and neuron -specific enolase in the pars distalis of quail, rat and human hypophyses. Histochemistry 86: 353-358 (1987).

Velasco, M. E., U. Roessmann and P. Gambetti: The presence of glial fibrillary acidic protein in the human pituitary gland. J. Neuropathol. Exp. Neurol. 41: 150 -163 (1982).

Vila-Porcile, E. and L. Olivier: The problem of the folliculo-stellate cells in the pituitary gland. In: (ed. by) P.M. MotTA: Ultrastructure of endocrine cells and tissues. Martinus Nijhoff Pub., Boston, 1984 (p. 64-76).

Virtanen, I., M. Miettinen, V.-P. Lehto, A-L. KaR INIEMI and R. PAasivuo: Diagnostic application of monoclonal antibodies to intermediate filaments. Ann. New York Acad. Sci. 455: 635-648 (1985).

Dr. D. Jesús Boya Vegue Department of Histology Faculty of Medicine University Complutense 28040 Madrid, Spain 